\title{
Death from occupational disease
}

\author{
Report it to the coroner or procurator fiscal; when in doubt request a necropsy
}

Pressure groups campaigning on behalf of victims of industrial lung disease are understandably keen that when a patient dies of such a condition a necropsy should be performed. In this they are at one with British law, which requires doctors to report to the coroner or, in Scotland, the procurator fiscal, cases in which an occupational disease contributed to death. ${ }^{1}$ Regrettably, especially in Scotland, this requirement is more honoured in the breach than in the observance. Necropsy is the most time honoured and revealing method of clinical audit, and it is ironic that as audit has become so fashionable, so necropsy has become less and less frequently obtained. ${ }^{2}$ Yet in cases of occupational disease not only is it easier to obtain consent for this procedure but it also has potential benefits to the deceased patient's relatives as well as in auditing the doctor's clinical skills.

The occupational diseases that most frequently result in death are those due to asbestos-asbestosis, with or without lung cancer, and mesothelioma. ${ }^{3}$ Coal workers' pneumoconiosis, silicosis, and lung cancer related to exposure to other workplace carcinogens, such as bischloromethyl ether and polycyclic aromatic hydrocarbons, are still responsible for deaths in Britain. In addition, chronic renal, hepatic, and neurological diseases in patients heavily exposed to solvents are often not attributed to the occupational cause and may lead to premature death. ${ }^{46}$

What should the doctor do when dealing with a patient with an occupational disease who has just died? The safest course is to report the death to the coroner or procurator fiscal, who will in most cases decide that a necropsy is necessary. For a general practitioner, this is often the only practicable step to take. If there is serious doubt whether the occupational disease contributed to death it is reasonable simply to obtain a necropsy and let the pathologist decide whether the death should be reported. This most frequently occurs when the patient is known to have been exposed to asbestos, does not have clinical evidence of asbestosis, and has died of lung cancer. A necropsy should always be requested in such patients as the likelihood that the asbestos exposure contributed to the cancer is increased if there is pathological evidence of asbestosis ${ }^{7}$; this evidence may be of considerable value in any subsequent litigation. More importantly, necropsy evidence allows the doctor to give an impartial and more confident explanation of the cause of death to bereaved relatives, allowing them to come more easily to terms with their loss and to make rational decisions about possible litigation.

Finally, it should be remembered that necropsy is not infallible. ${ }^{8}$ Patchy fibrosis is commonly present in the lungs of smokers, and distinguishing this from early asbestosis may be difficult. In such cases the expensive and time consuming procedure of quantification and identification of asbestos fibres in the lungs may be required. ${ }^{9}$ The necessary skill and equipment take it outside the reach of clinical pathology departments, and the results may still be equivocal; it is usually performed only for research or at the request and expense of lawyers and their clients.

ANTHONY SEATON

Professor

Department of Environmental and Occupational Medicine,

University Medical School,

Aberdeen AB9 2ZD

\footnotetext{
1 Start RD, Delargy-Aziz Y, Dorries CP, Silcocks PB, Cotton DWK. Clinicians and the coronial system: ability of clinicians to recognise reportable deaths. $B M F$ 1993;306:1038-41.

2 Lauder I. Auditing necropsies. BMF 1991;303:1214-5.

3 Department of Social Security. Social security statistics 1992. London: HMSO, 1992:227.

4 Bell GM, Gordon ACH, Lee P, Doig A, MacDonald MK, Thomson D, et al. Proliferative glomerulonephritis and exposure to organic solvents. Nephron 1985;40:161-5.

5 Redlich CA, West AB, Fleming L, True LD, Cullen MR, Riely CA. Clinical and pathological characteristics of hepatotoxicity associated with occupational exposure to dimethyl formalmide. Gastroenterol 1990;99:748-57.

6 Seaton A, Jellinek EH, Kennedy P. Major neurological disease and occupational exposure to organic solvents. Qf Med 1992;82:707-12.

7 Kipen HM, Lilis R, Suzuki Y, Valcuikas JA, Selikoff IJ. Pulmonary fibrosis in asbestos insulation workers with lung cancer: a radiological and histopathological evaluation. $\mathrm{Br} F$ Ind Med 1987;44:96-100.

8 Saracci R. Is necropsy a valid monitor of clinical diagnosis performance? BMJ 1991;303:898-900. 9 Rogghi VL. Fiber analysis. In: Rom WN, ed. Environmental and occupational medicine. 2nd ed. Boston: Little Brown, 1992:255-67.
}

\section{Will the new antipsychotics improve the treatment of schizophrenia?}

\author{
Depot preparations still hold the key to compliance
}

Non-compliance with neuroleptic treatment is an obstacle to the success of community care for patients with mental illness. It occurs in $8-16 \%$ of inpatients but in $33-54 \%$ of outpatients taking drugs by mouth. ${ }^{12}$ The rates are much lower with depot administration, ${ }^{3}$ and this accounts for its continued popularity. Non-compliant patients consume more resources; they are more severely ill at the point of admission than those who are readmitted despite compliance, they are more likely to be admitted compulsorily, they have longer inpatient stays, and they have a higher long term readmission rate. ${ }^{4}$ So how else (apart from depot treatment) might compliance be improved?

Attention to minimising extrapyramidal side effects is said to be important, ${ }^{5}$ although one study showed that non-compliance with treatment was even higher for antiparkinsonian drugs than for neuroleptics. Many other factors are known to relate to non-compliance with neuroleptic treatment: these include lack of insight, ${ }^{6}$ (which does not necessarily return after clinical recovery and may be interpreted as denial of illness and resistance to treatment ${ }^{7}$ ) and the occurrence of dysphoria or depression. ${ }^{8}$ One study showed a strong inverse relation between compliance and depression but not with the presence of extrapyramidal side effects. ${ }^{9}$ Other factors include galactorrhoea, ${ }^{10}$ coexistent alcohol abuse, ${ }^{11}$ poor or unstable housing, ${ }^{12}$ and a poor relation between patient and service providers. ${ }^{13}$

Compliance may be improved by creative approaches such as linking a free lunch to an injection at a morning depot clinic 
attended by hungry patients. ${ }^{14}$ At present, however, depot neuroleptics (even though they are no more effective than oral forms ${ }^{15}$ ) remain the best authenticated method of preventing relapse in non-compliant, forgetful or treatment-resistant patients. ${ }^{16}$

Will this picture change now that many new antipsychotics (generally referred to as atypical, although all this means is that they lack extrapyramidal side effects, which not all do) are becoming available? The atypical neuroleptics fall roughly into five groups: the later substituted benzamides; the mixed dopamine and serotonin receptor antagonists; the dopamine specific compounds; serotonin receptor antagonists; and sigma receptor antagonists. These new drugs differ from those in current use not only in their actions but also in their method of delivery. At present five of the six neuroleptics most used in Britain are available in depot form. About half the neuroleptics used in patients with schizophrenia are depot formulations. ${ }^{17}$

By contrast, few of the new drugs in development will initially be available as depot preparations. The dopamine receptor antagonist raclopride is being developed in depot form, as is the serotonin receptor antagonist sertindole, but generally the manufacturers have shown little enthusiasm for the extra work required to develop depot preparations. This is understandable for clozapine - no one would be keen to give a depot form of a drug known to carry a risk of causing agranulocytosis. No such risk is apparent from existing data on remoxipride, launched in 1991, and risperidone, launched in 1993. Attaching decanoate or ethanoate side chains to the atypical neuroleptics is not proving easy, but this is not the main reason for the lack of depot versions. Depot preparations are believed to be unnecessary-because they are thought to be needed only for drugs with unacceptable side effects.

The true atypical neuroleptics will, by definition, lack extrapyramidal side effects, but do the data support the comfortable assumption that non-compliance is caused principally by side effects? This has scarcely been proved for comparisons of serotonin reuptake inhibitors with tricyclic antidepressants, ${ }^{18}$ and the research reviewed earlier in this article has shown the multiple factors relevant to noncompliance with neuroleptic treatment. Might it not be premature to abandon our tried and trusted reliance on depot administration to overcome non-compliance in patients with schizophrenia?
At this stage it seems remarkably naive to assume that patients with chronic schizophrenia will readily swallow the neuroleptics in oral form. Quite possibly the negative symptoms of schizophrenia also influence compliance rates (largely unstudied) perhaps by being confounded with insight.

Insight itself, drug related depression, and other specific and non-specific psychological factors all play their parts in determining compliance. It would be unfortunate if marketing models built on naive assumptions delayed the introduction of new drugs likely to have a major impact on response to treatment. The delivery system most likely to offer the long term benefits of new drugs to patients with recalcitrant chronic schizophrenia is the well tried depot system.

TONY HALE

Senior lecturer in psychiatry

Department of Academic Psychiatry,

United Medical and Dental Schools of Guy's and St Thomas's Hospitals,

St Thomas's Hospital,

London SE1 7EH

1 Goad JD, Ezell JR. Drug-use evaluation programs for psychotropic medications. Am $\mathcal{f}$ Hosp Pharm 1990;47:132-6.

2 Van Putten T, Marder SR, Wirshing WC, Chabert N, Aravagiri M. Surreptitious noncompliance with oral fluphenazine in a voluntary inpatient population. Arch Gen Psychiatry 1990;47:786-7.

Johnson DAW, Wright N. Drug prescribing to schizophrenic outpatients on depot injection: repeat surveys over 18 years. Br f Psychiatry 1990;156:827-34.

McEvoy JP, Applebaum, PS, Apperson LJ, Geller J Freter $S$. Why must some schizophrenic patients be involuntarily committed. The role of insight? Compr Psychiatry 1989;30:13-7.

5 Frances AJ, Weiden P. Promoting compliance with outpatient drug treatment. Hosp Community Psychiatry 1987;38:1158-60.

6 Buchanan A. A two-year prospective study of treatment compliance in patients with schizophrenia. Psychol Med 1992;22:787-97.

7 David AS. Insight and psychosis. Br f Psychiatry 1990;156:798-808.

8 Bossert-Zaudig S, Dose M, Emrich HM, Garcia D, Junker M, Raptis K, et al. Psychological effects of previous treatment experiences with neuroleptics. Nervenarzt 1990;61:301-6.

9 Pan PC, Tantam D. Clinical characteristics, health beliefs with maintenance treatment: a comparison between regular and irregular attenders at a depot clinic. Acta Psychiatr Scand 1989;79:564-70

10 Zito JM, Sofair JB, Jaeger J. Self-reported neuroendocrine effects in women: a pilot study. Drug Intelligence and Clinical Pharmacy Annals of Pharmacotherapy 1990;24:176-80.

11 Pristach CA, Smith CM. Medication compliance and substance abuse among schizophrenic patients. Hosp Community Psychiatry 1990;41:1345-8.

12 Drake RE, Wallach MA, Teague GB, Freeman DH, Paskus TS, Clark TA. Housing instability and homelessness among rural schizophrenic patients. Am f Psychiatry 1991;148:330-6.

13 Corrigan PW, Liberman RP, Engel JD. From noncompliance to collaboration in the treatment of schizophrenia. Hosp Community Psychiatry 1990;41:1203-11.

14 Cassino T, Spellman N, Heiman J, Shupe J, Sklebar HJ. Invitation to compliance: the Prolixin brunch. ₹ Psychosoc Nurs Ment Health Serv 1987;25:15-9.

15 Rifkin A, Quitkin F, Rabiner CJ. Fluphenazine decanoate, fluphenazine hydrochloride given orally and placebo in remitted schizophrenics: relapse after one year. Arch Gen Psychiatr 1977:34:43-7.

16 Tegeler J, Lehmann E, Stockschlaeder M. Prophylactic efficacy of long-acting vs short-acting neuroleptics in schizophrenic out-patients. Nervenarzt 1980;511:654-61.

17 Hogarty GE. Depot neuroleptics. The relevance of psychosocial factors. $f$ Clin Psychiatry 1984;45:36-42.

18 Song F, Freemantle N, Sheldon TA, House A, Watson P, Mason J. Selective serotonin reuptake inhibitors: meta-analysis of efficacy and acceptability. BMf 1993;306:683-7.

\section{Public opinion and the NHS}

\section{The unaccountable in pursuit of the uninformed}

Criticising the current enthusiasm for gauging the public's opinion about the NHS and its services can easily sound undemocratic. Yet why public opinion should matter to the people running the NHS is not immediately clear.

Since 1979 the NHS has been transformed into a series of quangos directed mostly by businessmen with Conservative leanings, usually selected more for their professional position than for their identification with the local community. ${ }^{1}$ No body of administrative law has been developed to regulate their activities. ${ }^{2}$ Equipped with a mission statement of effectiveness and efficiency they have been freed from the constraints of formal accountability to those who use the NHS and pay for it through taxes. ${ }^{3}$

Despite their lack of accountability to the public they serve,
NHS managers are currently being exhorted by their political masters to listen to "local voices." Undoubtedly, the exhortations have spawned a lucrative industry in "communication strategies," the net cost of which has not been estimated. While health authorities and trusts pilot expensive public consultation exercises, sometimes in conjunction with other quangos, there is little evidence of any firm commitment to allow the public to influence purchasing decisions. ${ }^{4}$ The reason for this is obvious: quangos have no reason to be concerned with what the public think about them.

In Local Voices the NHS Management Executive tries to provide them with the necessary motivation. It says that involving local people in the purchasing process will enhance the credibility of health authorities, provide them with greater 